\title{
Flere mekanismer ved iskemisk hjerneskade
}

\section{En strøm av kalsiumioner inn}

i nervecellene kan være én av flere viktige årsaker til vevsskaden som oppstår ved hjerneslag.

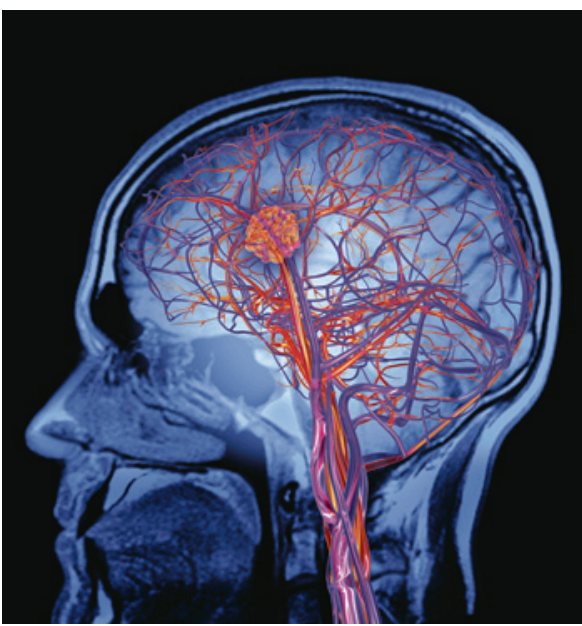

Illustrasjonsfoto: Science Photo Library
Ved iskemi i hjernen skades både nevroner og oligodendrocytter, som lager myelinskjeden rundt aksonene. Dermed forstyrres «trafikken» i nervenettverket i hjernen.

I en studie som nylig er publisert i tidsskriftet Nature, ble oligodendrocytter i rottecerebellum som var blitt utsatt for oksygenog glukosemangel, studert (1). En strøm av kalsiumioner inn i cellene virket toksisk, men oppsto annerledes enn i nevroner. Den ekstracellulære konsentrasjonen av transmitteren glutamat økte ved iskemi, men mens glutamatoverstimulering av NMDAreseptorer slipper toksiske strømmer av kalsiumioner inn i nevronene, var det en annen port for kalsium og andre kationer som åpnet seg i oligodendrocyttene, nemlig TRPA1holdige kanaler.

- Denne studien illustrerer kompleksiteten i nervesystemet. Flere mekanismer virker sammen, og hvilke som er viktigst, avhenger av betingelser og forsøksoppsett, sier Linda Hildegard Bergersen, som er professor i fysiologi ved Universitetet i Oslo og professor i aldringsnevrobiologi ved Køben- havns Universitet. Hun og andre forskere ved Institutt for medisinske basalfag ved Universitetet i Oslo har lenge forsket på iskemiske hjerneskader, og de har flere samarbeidsprosjekter med gruppen som står bak artikkelen i Nature.

- Virkningen av TRPA1-kanalen ved iskemi, som er påvist i hjerneskiver fra gnagere, kan være et nytt mulig angrepspunkt for behandling. Behandling med NMDAreseptorblokkere har ikke vært noen suksess ved hjerneslag hos mennesker, men tillegg av TRPA1-kanalblokkere kan kanskje gi bedre effekt. Videre fors $ø \mathrm{k}$ vil vise hvor viktig denne mekanismen er in vivo og hos mennesker, sier Bergersen.

\section{Haakon B. Benestad}

Universitetet i Oslo

Litteratur

1. Hamilton NB, Kolodziejczyk K, Kougioumtzidou E et al. Proton-gated $\mathrm{Ca}(2+)$-permeable TRP channels damage myelin in conditions mimicking ischaemia. Nature 2016: 529: 523-7.

\section{Signalvei som biomarkør ved nevroblastom}

\author{
En matematisk modell basert på pasientens eget genuttrykk kan pre- \\ dikere prognose og behandlingsforløp ved nevroblastom. Kan skredder- \\ sydd behandling av pasienter med denne tilstanden snart bli virkelighet?
}

Pasienter med nevroblastom klassifiseres i risikogrupper basert på informasjon om sykdomsstadium, alder og status til biomarkøren MYNC. Oppregulering av MYNC hos pasienter med nevroblastom er assosiert med høy risiko. Men denne biomarkøren er lite presis. Man ønsket derfor å finne ut om JNKsignalering, en kinasekaskadesignalvei som påvirker celledød, kunne gi mer presis informasjon om sykdomsstatus (1).

Til forskjell fra i tidligere studier ønsket man å se på muligheten for å bruke en fullstendig signaleringsvei som biomarkør. SHSY5Y, en nevroblastomcellelinje, ble brukt i kartleggingen. Alle komponentene involvert i JNK-signalering og komponenter i tilstøtende prosesser ble kartlagt i SH-SY5Y-cellene. Ulike stressresponser som påvirket signaleringen ble systematisert. Resultatene fra kartleggingen ble satt sammen i en matematisk modell som demonstrerte hvordan JNKsignaleringen reguleres. Fra denne modellen kunne man predikerer prognose ved nevroblastom. Ved å bruke genekspresjonsdata fra pasienter $(\mathrm{n}=109)$ ble modellen brukt til å predikere individuell risiko. Resultatet fra matematisk predikert risiko ble validert ved å sammenligne dataene opp mot registre med overlevelsesdata for pasienter.

- Dette er en meget komplisert og interessant studie, sier professor og overlege Trond Flægstad ved Barne- og ungdomsklinikken, Universitetssykehuset Nord-Norge og Universitetet i Tromsø. - Den viser at aktiviteten av en spesiell signalvei er en markør for utfall ved nevroblastom. På sikt kan dette danne grunnlag for persontilpasset behandling som kan være mer effektiv og mindre plagsom enn den vi har i dag, sier han.

\section{Ruth Halsne}

Tidsskriftet

\section{Litteratur}

1. Fey D, Halasz M, Dreidax D et al. Signaling pathway models as biomarkers: Patient-specific simulations of JNK activity predict the survival of neuroblastoma patients. Sci Signal 2015; 8: ra130.

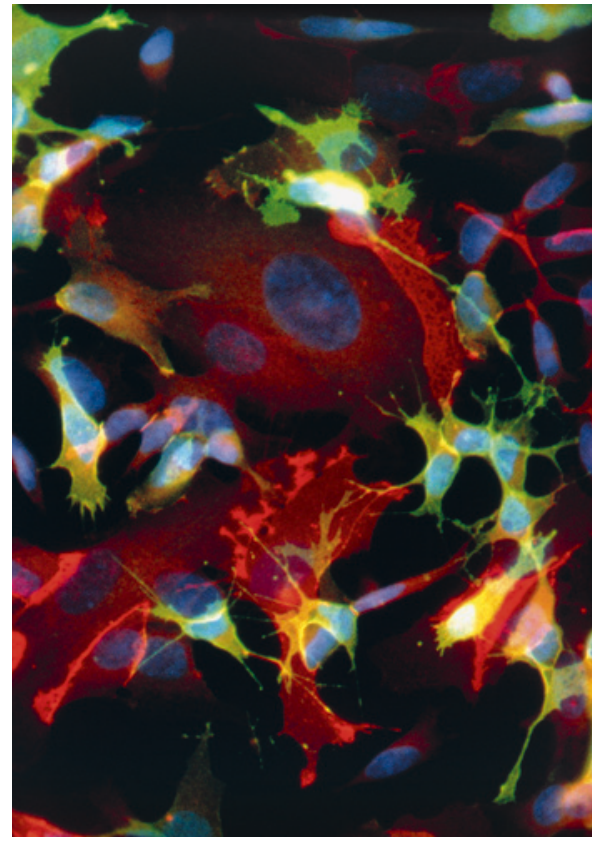

Nevroblastomceller. Foto: Science Photo Library 